William \& Mary Law School

William \& Mary Law School Scholarship Repository

\title{
Antitrust and the Information Age: Section 2 Monopolization Analyses in the New Economy
}

A. Benjamin Spencer spencer@wm.edu

Follow this and additional works at: https://scholarship.law.wm.edu/facpubs

Part of the Antitrust and Trade Regulation Commons, Courts Commons, and the Science and Technology Law Commons

\section{Repository Citation}

Spencer, A. Benjamin, "Antitrust and the Information Age: Section 2 Monopolization Analyses in the New Economy" (2001). Faculty Publications. 1973.

https://scholarship.law.wm.edu/facpubs/1973

Copyright c 2001 by the authors. This article is brought to you by the William \& Mary Law School Scholarship Repository.

https://scholarship.law.wm.edu/facpubs 


\title{
ANTITRUST AND THE INFORMATION AGE: SECTION 2 MONOPOLIZATION ANALYSES IN THE NEW ECONOMY
}

\author{
If you don't let the players play ... you can ruin the game. Markets are rough places \\ and, though competition is not always pretty, allowing it to flourish is ultimately in our \\ best interest. 1
}

On April 3, 2000, U.S. District Judge Thomas Penfield Jackson declared that the Microsoft Corporation ("Microsoft") had maintained monopoly power in the personal computer operating system market by anticompetitive means, ${ }^{2}$ in violation of Section 2 of the Sherman Antitrust Act. ${ }^{3}$ A case of enormous significance, Microsoft raises difficult questions regarding how antitrust laws should be applied to information technology ("IT") companies. Specifically, many characteristics of what has come to be called the "New Economy" - and of the IT companies within it - suggest that traditional monopolization analysis may need modification. As the U.S. has moved toward an information-based network economy, the need for a specialized set of rules for participants in IT markets has become increasingly clear.

This Note discusses the characteristics of the IT economy relevant to competition and market dominance and considers how these characteristics should inform a Section 2 analysis. Part I reviews Section 2 jurisprudence, describing the standards that courts generally employ to evaluate a Section 2 monopolization claim. Part II discusses aspects of the New Economy that bear on competition among IT companies, highlighting those forces that foster single-firm market dominance and those that influence competitive strategies. Part III argues that certain attributes of the New Economy warrant a revision of the present approach to Section 2 analysis in an IT context and concludes by applying the revised approach to the facts of the Microsoft case.

\section{TRADITIONAL SECTION 2 ANALYSIS}

With consumer protection as its goal, ${ }^{5}$ Section 2 of the Sherman Act makes it unlawful to "monopolize, or attempt to monopolize,

\footnotetext{
1 Joel I. Klein, The Importance of Antitrust Enforcement in the New Economy, Address Before the New York State Bar Association, Antitrust Law Section (Jan. 29, 1998), available at http:// www.usdoj.gov/atr/public/speeches/I338.htm.

2 United States v. Microsoft Corp., 87 F. Supp. 2d 30, 39 (D.D.C. 2000).

3 I5 U.S.C. 8 2 (I 994 ).

4 See, e.g., Progressive Policy Institute, The New Economy Index - Introduction, at http://www.neweconomyindex.org/introduction.html (last visited Feb. 19, 2001).

5 Consumer welfare is the preeminent consideration in antitrust analysis. See Reiter v. Sonotone Corp., 442 U.S. 330, 343 (r979) (noting that "Congress designed the Sherman Act as a 'consumer welfare prescription'"). Although monopolistic behavior can and often does have a deleterious impact on competing firms, courts have consistently admonished litigants and regulators that
} 
... any part of the trade or commerce among the several States, or with foreign nations." 6 Despite the Act's absolute language, courts have not interpreted it to outlaw all interstate monopolies. Rather, the intended purpose of the statute is to prohibit the acquisition or maintenance of monopoly power through anticompetitive means. ${ }^{7}$

Although the provision is crafted in admittedly broad terms, the legislative history of Section 2 "makes it perfectly clear that [Congress] expected the courts to give shape to the statute's broad mandate by drawing on common-law tradition." 8 In United States v. Grinnell Corp.,${ }^{9}$ the Supreme Court distilled the monopolization offense of Section 2 into two elements: "( 1 ) the possession of monopoly power in the relevant market and (2) the willful acquisition or maintenance of that power as distinguished from growth or development as a consequence of a superior product, business acumen, or historic accident."10

\section{A. Monopoly Power in the Relevant Market}

To evaluate the first element of the Grinnell test, courts generally rely upon the concept of monopoly power set forth in United States $v$. E.I. $d u$ Pont de Nemours \& Co.:1" "Monopoly power is the power to control prices or exclude competition." 12 Such power need not be exercised; the test is satisfied if a firm merely possesses this power. ${ }^{13}$

To establish the existence of monopoly power, it is necessary first to identify what courts call the "relevant market" - the market in which an entity is alleged to be able to control prices or to restrain competition. Identifying the relevant market is important because, according to the Supreme Court, "[w]ithout a definition of that market there is no way to measure [a firm's] ability to lessen or destroy competition."14 In defining the relevant market, "no more definite rule can be declared than that commodities reasonably interchangeable by consumers for the same purposes make up that part of the trade or commerce, mo-

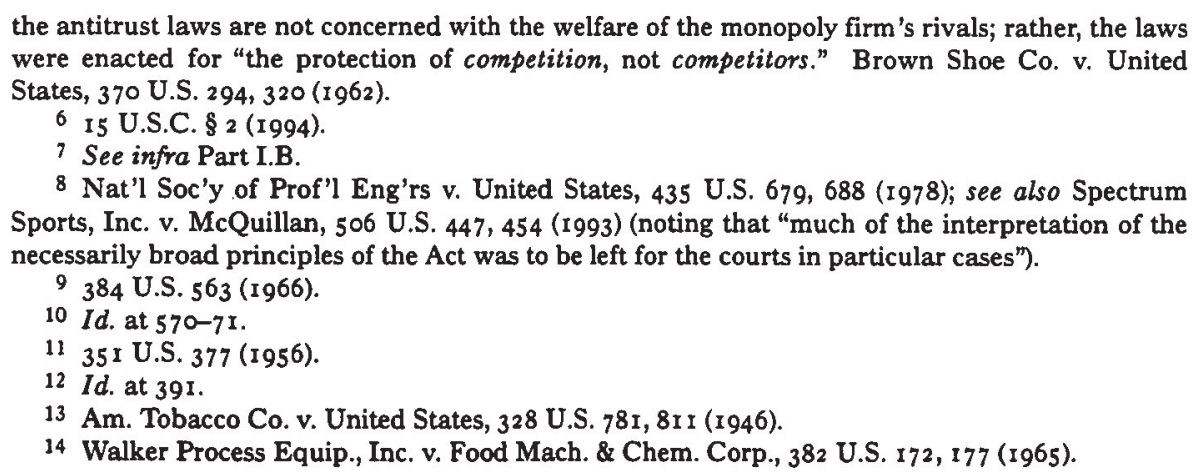


nopolization of which may be illegal."15 Such a conception makes sense because the possibility of consumer substitution prevents firms from engaging in anticompetitive pricing.

Once the relevant market is identified, evidence of monopoly power within that market must exist. Courts rely on several types of evidence in order to assess whether a firm enjoys such power. The most widely adopted approach is that a finding of dominant market share in conjunction with substantial barriers to entry is sufficient to create the presumption of monopoly power.

I. Market Share. - In the absence of direct evidence that a firm is exercising actual control over prices or excluding competition, ${ }^{16}$ courts typically assess a defendant's share of the relevant market - in conjunction with an array of other factors - to determine whether a monopoly exists. ${ }^{17}$ There is no fixed market share percentage that will automatically result in a finding of monopoly power; ${ }^{18}$ however, a set of rough guidelines has emerged that courts use to weigh the relevance of a particular market share. Market share above seventy percent typically suffices to support an inference of monopoly power. ${ }^{19}$ Conversely, courts have rarely found monopoly power when a firm's market share is below fifty percent, leaving some uncertainty as to market shares between fifty and seventy percent. ${ }^{20}$

2. Barriers to Entry. - Courts consider a number of other factors and circumstances in monopolization analysis. ${ }^{21}$ The most prevalent

15 E.I. du Pont, 35 I U.S. at 395 (internal quotation marks omitted). Courts (and economists) refer to the willingness of consumers to substitute as "cross-elasticity of demand." Id. at 394.

16 See, e.g., FTC v. Ind. Fed'n of Dentists, 476 U.S. 447, 460-6r (1986) ("[P]roof of actual detrimental effects, such as a reduction of output, can obviate the need for an inquiry into market power, which is but a surrogate for detrimental effects." (internal quotation marks omitted)); Rebel Oil Co. v. Atlantic Richfield Co., 5 I F.3d I42 I, I434 (gth Cir. 1995) ("If the plaintiff puts forth evidence of restricted output and supracompetitive prices, that is direct proof of the injury to competition which a competitor with market power may inflict, and thus, of the actual exercise of market power.").

17 See, e.g., E.I. du Pont, 35 I U.S. at $39 \mathrm{r}$.

18 See United States v. Columbia Steel Co., 334 U.S. 495, 527-28 (I948) ("We do not undertake to prescribe any set of percentage figures by which to measure the reasonableness of a corporation's enlargement of its activities by the purchase of the assets of a competitor. The relative effect of percentage command of a market varies with the setting in which that factor is placed.").

19 See, e.g., Int'l Boxing Club v. United States, 358 U.S. 242, 249 (1959) (finding monopoly power based on a $93 \%$ market share); E.I. du Pont, 35 I U.S. at 379, 39I (stating that control of $75 \%$ of a relevant market would constitute monopoly power); Morgenstern v. Wilson, 29 F.3 I I29I, 1296 n.3 (8th Cir. 1994) (80\% sufficient); Heatransfer Corp. v. Volkswagenwerk, A.G., 553 F.2d 964, 98I (5th Cir. 1977) (71\% to $76 \%$ sufficient).

20 See AM. BAR AsS'N, ANTitrust LAW Developments 235-36 (4th ed. 1997) (noting the $50 \%$ and $70 \%$ benchmarks and citing supporting federal case law).

21 AM. BAR ASS'N, supra note 20 , at 238 \& n.45 (listing factors such as "presence and degree of barriers to entry or expansion, technological superiority resulting in cost advantages, economies of scale and scope, ability to price discriminate, the relative size of competitors, competitors' per- 
of these factors is the presence and extent of barriers to entry. Barriers to entry make it more difficult for firms to begin competing in the relevant market, thereby insulating an incumbent firm from competition, ${ }^{22}$ which can prevent the incumbent firm from charging or maintaining monopoly prices. ${ }^{23}$ As a result, barriers to entry are not significant for antitrust analysis purposes "when natural market forces will likely cure the problem." ${ }^{24}$ Therefore, notwithstanding the existence of barriers to entry, when other market forces - such as innovation away from an incumbent product - could create competitive pressures on a dominant firm, no antitrust concerns arise and "judicial intervention into the market is unwarranted." 25

\section{B. Willful Acquisition or Maintenance of Monopoly Power}

In addition to monopoly power, under the Grinnell formulation courts must also find that there has been a "willful acquisition or maintenance of that power as distinguished from growth or development as a consequence of a superior product, business acumen, or historic accident."26 This willfulness or intent requirement is critical because it avoids punishing firms that obtain a dominant market share as a result of successful competition for their success. ${ }^{27}$ The competition ethic thus demands that a monopolist retain the ability to compete: "A monopolist, no less than any other competitor, is permitted and indeed encouraged to compete aggressively on the merits ...."28 Indeed, the possibility that monopolists will cease competing on price, quality, or innovation is a concern that Section 2 seeks to address.

Distinguishing lawfully acquired and maintained monopoly power from objectionable monopoly power has been a difficult task for courts. However, the cases do reveal a common approach to evaluat-

formance, pricing trends and practices, homogeneity of products, potential competition, and the stability of market shares over time").

22 See, e.g., Matsushita Elec. Indus. Co. v. Zenith Radio Corp., 475 U.S. 574, 591 n.15 (I986) ("W[W]ithout barriers to entry it would presumably be impossible to maintain supracompetitive prices for an extended time.").

23 See Rebel Oil Co., Inc. v. Atlantic Richfield Co., 5 I F.3d I42 I, I439 (9th Cir. 1995). Courts have given this factor tremendous weight, refusing to find firms with up to $100 \%$ market share to be monopolies in light of the extreme ease of entry into the relevant market. See, e.g., Los Angeles Land Co. v. Brunswick Corp., 6 F.3d I422, 1425-26, I429 (9th Cir. I993) (holding that the defendant's $100 \%$ market share did not constitute a monopoly given the ease of entry into the local bowling services market); accord Fabrication Enters. v. Hygenic Corp., 848 F. Supp. 1 I56, I I60 (S.D.N.Y. I994), rev'd on other grounds, 64 F.3d 53 (2d Cir. I995).

24 Rebel Oil, 5 I F.3d at 1439.

25 Id.

26 United States v. Grinnell Corp., 384 U.S. 563, $570-7$ I (1966).

27 Judge Learned Hand so remarked when he wrote, "The successful competitor, having been urged to compete, must not be turned upon when he wins." United States v. Aluminum Co. of Am., I48 F.2d 416,430 (2d Cir. 1945).

28 Foremost Pro Color, Inc. v. Eastman Kodak Co., 703 F.2d 534, 544 (9th Cir. I983). 
ing market conduct under Section 2. The key question is whether the conduct of the dominant firm indicates competition on the merits (meaning competition based on product quality, marketing and distribution, and consumer choice), which naturally but only incidentally tends toward the exclusion of competitors, or whether the conduct is directly or primarily aimed at excluding competitors on a basis other than the merits. ${ }^{29}$ The latter type of conduct is variously labeled "anticompetitive," "exclusionary," or "predatory." 30

In making such a determination, many courts have inquired whether conduct that is seemingly irrational for a profit-maximizing firm becomes rational only in light of its adverse impact on competition. ${ }^{31}$ The most common example of this type of conduct is predatory pricing, which is "pricing below an appropriate measure of cost for the purpose of eliminating competitors in the short run and reducing competition in the long run." 32

However, an accurate inquiry into the rationality of business conduct must be rooted in a sophisticated understanding of the marketplace and the nature of competition in the relevant sphere. Thus "penetration pricing" - discounting or giving away a product in order to establish a market presence - is an example of a practice that can appear predatory but is in fact wholly rational and necessary in an IT context. ${ }^{33}$ The courts must understand many other details of the IT marketplace in order to determine properly whether firms have run afoul of Section 2's prohibition. This Note now considers those details.

\section{MARKET REALITIES OF THE NEW ECONOMY}

The world is currently undergoing a fundamental economic transformation. A combination of technological developments - powerful personal computers, high-speed telecommunications, and the Internet - has created a new market environment variously referred to as the "information economy," the "network economy," the "knowledge economy," or simply the "New Economy." 34 This New Economy is an-

29 See, e.g., Aspen Skiing Co. v. Aspen Highlands Skiing Corp., 472 U.S. 585, 605 (1985) ("If a firm has been attempting to exclude rivals on some basis other than efficiency, it is fair to characterize its behavior as predatory." (internal quotation marks omitted)).

30 Id. at 602 .

31 See, e.g., Olympia Equip. Leasing Co.v. W. Union Tel. Co., 797 F.2d 370, 378 (7th Cir. 1986) ("The monopolist cannot be faulted for wanting to sell more output unless he is engaged in some predatory or exclusionary scheme the long-run effect of which may be to restrict output ....").

32 Cargill, Inc. v. Monfort of Colo., Inc., 479 U.S. 104, I 7 (I986).

33 See Michael L. Katz \& Carl Shapiro, Systems Competition and Network Effects, 8 J. ECON. PERSP. 93, IO4 (I994). Part II, below, describes the unique pricing structure of information goods.

34 See Progressive Policy Institute, supra note 4. 
chored primarily in the production, processing, and dissemination of such information goods as software, content, or expertise.

To be sure, there is nothing new about the existence of information goods; music and books, for example, have existed as information goods for quite some time. What is new, however, is the dominance of information goods in the total marketplace ${ }^{35}$ and the present pace of major technological advances. The technological revolution impacts the cost and distribution of such goods in a way that fundamentally alters how their purveyors must operate. Many attributes of the New Economy have antitrust implications. This Part discusses the most relevant of these characteristics, leaving for Part III the task of analyzing their impact on traditional monopolization analysis.

\section{A. Negligible Marginal Costs}

Information goods generally feature high initial fixed costs and negligible marginal costs, which generate increasing returns and vast economies of scale. ${ }^{36}$ The traditional understanding of the market economy was based in large part upon the assumption of diminishing returns: "[P]roducts or companies that get ahead in a market eventually run into limitations, so that a predictable equilibrium of prices and market shares is reached."37 Such limitations include increasing marginal costs, declining access to raw materials, and exhaustion of consumer demand. ${ }^{38}$ The general applicability of this assumption, however, has eroded as the United States has moved from a manufacturing and resource-processing-based economy to a knowledge-based economy. As opposed to traditional goods, the costs associated with the initial creation of information goods are extremely high; for example, the compilation of information for an encyclopedia, the production of a movie, and the development of software each entails significant "firstcopy costs." 39

Significant to antitrust law is the fact that these high initial fixed costs are accompanied by negligible marginal costs associated with mass-production. For example, the costs of stamping multiple CDROMs with a software program or producing DVDs for a particular

35 See, e.g., ANNE LEER, WELCOME TO THE WIRED WORLD 56 (2000) ("The trading of intellectual property commodities - information assets - is becoming more and more significant in the world economy.").

36 Economies of scale "occur when mass producing a good results in lower average cost." Introductory Economics Revision Notes - Economies of Scale, at http://www.bized.ac.uk/stafsup/ options/notes/econ204.htm (last visited Feb. I9, 200I).

37 W. Brian Arthur, Increasing Returns and the New World of Business, in THE KNOWLEDGE ECONOMY 75, 75 (Dale Neef ed., I998).

38 See id. at 76.

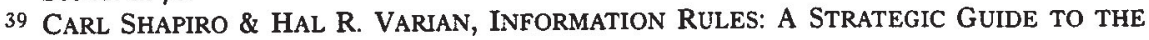
NETWORK ECONOMY 20 (I999). 
movie are miniscule. ${ }^{40}$ And as digital reproduction and distribution of information costs virtually nothing, initial fixed costs have become an even greater portion of total production costs. ${ }^{41}$

This cost structure turns the traditional understanding of the market economy on its head, because firms can enjoy increasing rather than diminishing returns. ${ }^{42}$ Increasing returns create the potential for vast economies of scale, which give larger firms a market advantage: because their unit costs will likely be substantially lower, it will be easier to corner a market and difficult for new entrants to compete. ${ }^{43}$

\section{B. Value-based Pricing}

With respect to the production of information goods, then, costbased pricing is inappropriate; because the marginal cost per unit approaches zero, price cannot be based on a percentage markup from the marginal cost as traditional pricing methods prescribe. ${ }^{44}$ Rather, price determinations must be based on consumer value - what various consumers are willing to pay based on the value they assign to the product. This approach is referred to as "value-based pricing." 45 The main economic implication of value-based pricing is that IT firms will engage in a range of pricing strategies, such as versioning, ${ }^{46}$ that completely confound the traditional notion of a single "appropriate," costbased price level.

\section{Intellectual Property Protection}

Information goods also differ from material goods by virtue of their enjoyment of copyright or patent protection. ${ }^{47}$ Information products consisting of protected intellectual property are under the exclusive control of their proprietors, thus giving these proprietors monopolistic control over the production and distribution of the information or technology. Information markets occupied by protected products, therefore, tend to favor dominance by proprietary firms.

$40 \mathrm{~W}$. Brian Arthur offers the example of Microsoft's Windows software: "The first disk of Windows to go out the door cost Mircrosoft $\$ 50$ million; the second and subsequent disks cost $\$ 3$." Arthur, supra note 37 , at 78 .

41 See id.

42 See id. at 75-78.

43 See Knowledge Is Power, ECONOMIST, Sept. 23, 2000, at 27, 30.

44 See SHAPIRO \& VARIAN, supra note 39 , at 3.

45 See id. For example, publishers initially release a hardcover version of a book for those who want to read immediately and issue a cheaper paperback version later for those who can wait; the production cost of each version is virtually the same, while the market price is significantly different. See id. at 4.

$46 I d$. at 53-54 (defining versioning as "offering your information product in different versions for different market segments").

47 Such protection derives from the Copyright Act, I7 U.S.C. § ror et seq. (I994 \& Supp. IV 1998), and the Patent Act, 35 U.S.C. § I et seq. (r994 \& Supp. IV 1998). 


\section{Information as an Experience Good}

One of the defining attributes of information goods is their status as experience goods - goods that consumers must experience in order to value. ${ }^{48}$ A person cannot determine whether he or she wants to see a movie, buy a compact disc, or read a book without first experiencing its content in some way, such as through a preview, radio play, or descriptive book jacket, respectively. ${ }^{49}$ Likewise, the product offerings of IT firms require previewing, forcing IT firms to engage in marketing strategies peculiar to such products. ${ }^{50}$ Over time, incumbent firms can rely on reputation and name brand as signals to consumers that their future information goods will be desirable, lessening the need to rely on experience facilitation. Prior to a firm's establishing itself, however, the experience good problem remains serious. Purveyors of such goods must confront an enduring dilemma: "The tension between giving away your information - to let people know what you have to offer - and charging them for it to recover your costs is a fundamental problem in the information economy." 51 This tension necessitates pricing and marketing strategies that can appear anticompetitive but are actually consistent with competition in the IT field.

\section{E. Network Effects and the Need for Standards}

The New Economy is increasingly characterized by networks ${ }^{52}-$ "a mixture of facilities and rules that allow a firm or group of firms to exchange or share transactions, data, electronic impulses, information, energy, or physical traffic." 53 These networks exhibit "network externalities," whereby "the utility that a user derives from consumption of the [network] good increases with the number of other agents consuming the good."54 For example, a fax machine only has value to the extent that there are other fax machines with which it can communicate. As more people acquire fax machines, it becomes more valuable to have one.

\footnotetext{
48 SHAPIRO \& VARIAN, supra note 39 , at 5.

49 See id. at 85.

50 For example, firms can offer free samples of the product or make the good available at a promotional price in order to facilitate trial experiences with the good. See id. at 86.

51 Id. at 6.

52 See William J. Kolasky, Network Effects: $A$ Contrarian View, 7 GEO. MASON L. REV. 577, 577 (1999) (" $[\mathrm{N}]$ etwork industries represent an increasingly large part of the economy. As markets became more global and as knowledge-based industries became more important, networks have become an increasingly important mode for organizing productive activities.").

53 David A. Balto, Networks and Exclusivity: Antitrust Analysis To Promote Network Competition, 7 GEO. MASON L. REV. 523, 523 (1999).

54 Michael L. Katz \& Carl Shapiro, Network Extermalities, Competition, and Compatibility, 75 AM. ECON. REV. 424, 424 (I985).
} 
While communications networks provide the most salient example of network externalities, strong network effects exist in "virtual" networks as well. Virtual networks consist of users connected merely by their use of a common system or standard, as opposed to the direct connectivity of the possessed goods. ${ }^{55}$ An example of a virtual network is the aggregation of consumers who use VHS-compatible VCR machines and tapes. Participants in this network benefit from compatibility among machines: the large network encourages production of video material in the VHS format because producers can be assured of significant demand for such products.

Network externalities can provide the impetus for exponential growth in the adoption of a particular technology. This growth is a result of the positive feedback that each new user generates. ${ }^{56}$ In markets in which positive feedback is strong, only one firm can win; ${ }^{57}$ consequently, the drive to become consumers' preferred choice is imperative, making market share-enhancing strategies, such as penetration pricing, key to generating the positive feedback loop. Another implication of network externalities is that a significant first-mover advantage exists: early and decisive action in a field can secure a head start at winning over consumers.

Network economies require standards to function properly: within a network there must be conventions or commonalities that allow network participants to interact.58 Examples of such technological standards include video recording formats, telecommunications protocols, and computer operating systems. Consumers demand common standards because "users seek and desire predictability, compatibility, and interoperability." 59 In new technological fields, developing the accepted standard can be costly and risky as well: the need for a uniform standard often means that only one firm can succeed. Indeed, the winner-take-all quality of initial standards battles means that there will tend to be one dominant market entity occupying a field.

\section{F. Consumer Lock-in Effect}

Lock-in effects abound in IT markets, occurring whenever a consumer becomes so committed to a particular product that she cannot

55 See Katz \& Shapiro, supra note 33 , at $97-98$.

56 SHAPIRO \& VARIAN, supra note 39 , at 13.

57 Id. at 176

58 See S.J. Liebowitz \& Stephen E. Margolis, Should Technology Choice Be a Concern of Antitrust Policy?, 9 HARV. J.L. \& TECH. 283, 29I (1996). Liebowitz and Margolis use the term "synchronization" to refer to "the benefit received by users of a standard when they interact with other individuals using the same standard." Id. at 292.

59 Peter Brown \& Lauren McCollester, Should We Kill the Dinosaurs or Will They Die of Natural Causes?, g CORNell J.L. \& PUB. POL'Y 223, 235 (I999). 
switch to a competing product without incurring significant costs. ${ }^{60}$ These switching costs can include the cost of acquiring new equipment or technology; the transaction cost of switching suppliers (including search costs); the cost of learning to use new equipment and functioning in the new technological environment; consumer uncertainty about the quality of untested brands; foregone benefits of loyalty programs, such as frequent flyer programs; and psychological brand loyalty. ${ }^{61}$ To induce consumers to switch, the benefits of the new technology must outweigh these costs.

Although not unique to network markets, switching costs are particularly high in networked industries unified by a common standard. To the extent that incumbent technology enjoys its status as the common standard and a networked good, switching is only beneficial if a significant group of consumers do so en masse, as when consumers switched from audiotapes to compact disc technology.

\section{G. "The Next Big Thing" and the Rapidity of Innovation}

One of the hallmarks of the IT economy is the speed of technological change and innovation. Competition in the IT economy focuses primarily on trying to develop "the Next Big Thing."62 The prime mover of the New Economy is not the pursuit of enhanced production efficiencies, as in the past, but rather "the introduction of entirely new technologies or problem-solving services that create new markets."63 This drive has resulted in rapid technological advances, ${ }^{64}$ creating an extremely dynamic marketplace in which new technologies have caused costs - and thus prices - to fall as functionality and utility continue to improve. ${ }^{65}$

The threat of the Next Big Thing prevents incumbents from resting on their laurels and stimulates innovation. With potential future com-

60 SHAPIRO \& VARIAN, supra note 39 , at 104.

61 Paul Klemperer, Competition When Consumers Have Switching Costs: An Overview with Applications to Industrial Organization, Macroeconomics, and International Trade, 62 REV ECON. STUD. 515, 517-18 (1995). For example, a user of a Macintosh computer considering switching to an Intel-compatible computer faces the prospect of acquiring new hardware and software and learning how to use the new system and its accompanying programs.

62 This aspect of the New Economy is known as the "killer application" or "killer app" phenomenon. Randall S. Hancock, The Quest for Killer Applications, in MASTERS OF THE WIRED WORLD 208 (Anne Leer ed., I999).

63 Dale Neef, The Knowledge Economy: An Introduction, in THE KNOwLEdGe ECONOMY, supra note 37 , at 4 .

64 See, e.g., LEER, supra note 35, at 34-35 ("The convergence and marrying together of computing, media and communications technologies has [sic] resulted in a phenomenal development of new applications and electronic appliances.").

65 See id. ("Prices continue to fall while the quality of functionality improves. Customers are getting used to having more for less."). The declining costs of computers and cellular phones, in conjunction with their improved performance, support this observation. 
petition pressuring firms at least as much as current competition, a firm's dominance remains under a constant threat that prevents it from engaging in monopolistic behavior. Furthermore, the rapidity of technological change can mean that hegemony is short-lived.

\section{SECTION 2 ANALYSIS AND THE NEW ECONOMY}

The Information Age has precipitated dramatic changes in the business landscape. To achieve success or simply to remain viable, firms now must adopt new and creative business policies. What impact, if any, should the advent of the Information Age and the accompanying characteristics of the knowledge economy have on monopolization analysis under Section 2 of the Sherman Act? After a brief survey of the views of academics and antitrust regulators on the matter, this Part suggests that the characteristics of the New Economy require an alteration of current Section 2 analysis under the Grinnell formulation. ${ }^{6} 6$

\section{A. Perspectives on Antitrust Analysis in the New Economy}

The consensus among antitrust regulators appears to be that old antitrust principles do not require modification in the New Economy. ${ }^{67}$ Moreover, regulators ardently maintain that increased suspicion is warranted in the area of high technology; because market dominance comes more naturally, it is more necessary for regulators to guard against abuses of power by dominant firms. ${ }^{68}$

Academic writers echo these sentiments. Salop and Romaine remark that "exclusionary conduct may be particularly pernicious since [the New Economy's] market features tend to make monopolies more durable." 69 Furthermore, Salop and Romaine conclude that monopoly power tends to exist in network markets due to the tendency toward

66 See supra p. 1624 .

67 See, e.g., Joel I. Klein, Rethinking Antitrust Policies for the New Economy, Address Before the Haas/Berkeley New Economy Forum (May 9, 2000), available at http://www.usdoj.gov/atr/ public/speeches/4707.htm; see also Daniel L. Rubinfeld, Competition, Innovation, and Antitrust Enforcement in Dynamic Network Industries, Address Before the Software Publishers Association (Mar. 24, I998), at http://www.usdoj.gov/atr/public/speeches/I6r I.htm ("I am confident . . that the existing array of antitrust tools, including the Sherman Act and the Clayton Act, are adequate to the task [of enforcing pro-competitive behavior in high technology industries].").

68 See Rubinfeld, supra note 67 (declaring that the antitrust authorities should "make every effort to ensure that dominant incumbent firms with monopoly power ... not use their substantial market power to harm innovation, to retard technological progress, and ultimately to harm consumers ${ }^{m}$.

69 Steven C. Salop \& R. Craig Romaine, Preserving Monopoly: Economic Analysis, Legal Standards, and Microsoft, 7 GEO. MASON L. REV. 6I 7, 618 (I999) (commenting on the Microsoft case). 
[Vol. I $14: 1623$

large market shares and the high entry barriers that network effects can create. ${ }^{70}$

Although regulators and academics recognize many of the unique attributes of the New Economy, they tend to downplay the impact of these attributes on monopolization analysis. This Part discusses how aspects of the New Economy should impact a Grinnell analysis and argues that these attributes call for less, rather than more, alarm at market dominance in high technology contexts.

\section{B. Determining Monopoly Power in New Economy Markets}

The market forces described in Part II foster single-firm dominance in IT markets. In light of this fact, the traditional market-share-plusbarriers-to-entry approach to finding monopoly power under the first prong of Grinnell loses much of its utility. Because large market share and barriers to entry are par for the course in IT markets, and because Grinnell's approach does not adequately account for the enormous impact of innovation, such an approach can lead courts to conclude that a firm possesses monopoly power when a more sophisticated analysis might reveal otherwise. After elaborating how aspects of IT markets facilitate large market shares and barriers to entry, this section suggests an alternative method of determining whether a firm holds monopoly power.

I. Market Dominance in Information Technology Markets. Dominance in IT markets seems to be the rule rather than the exception. The very nature of knowledge as a commodity naturally tends toward monopolization, or at least requires such for profitability. Former U.S. Treasury Secretary Larry Summers perhaps best captured this idea when he stated that "[t]he only incentive to produce anything [in the information economy] is the possession of temporary monopoly power ... without that power, the price will be bid down to marginal cost and high fixed costs cannot be recouped." 1

Indeed, many of the market attributes outlined in Part II foster market dominance in the IT sector. The negligible marginal costs associated with the production and distribution of IT products are fundamental to understanding market dominance in the New Economy. Increasing returns and economies of scale give a direct advantage to larger firms, whose unit costs are significantly lower than their competitors'. Moreover, the cost structure of IT products dictates that "markets for information will not, and cannot, look like textbook-

$70 I d$. at 620 .

71 Knowledge Is Power, ECONOMIST, Sept. 23, 2000, at 3I. An example illustrates that competition among sellers of commodity information pushes prices toward zero: phone directories compiled onto compact discs initially sold for $\$ 10, \infty 00$; today they sell for less than $\$ 20$. SHAPIRO \& VARIAN, supra note 39 , at 23-24. 
perfect competitive markets in which there are many suppliers offering similar products, each lacking the ability to influence prices," 72 because, as noted above, negligible marginal cost drives prices of information goods toward zero.

Similarly, network effects, which lead to the mass adoption of a standardized product, facilitate single-firm market dominance. Only one or a handful of networks tend to survive in any given market, ${ }^{73}$ meaning that the firm or firms behind such networks will likely become dominant. To the extent that the network is centered around proprietary information, such as Microsoft's operating system technology, the proprietary firm is even more likely to enjoy a monopoly.

IT market forces solidify incumbent dominance by raising barriers to entry. Because marginal cost is negligible, once a firm wins the initial battle for dominance, that firm's production cost advantage allows it to beat anyone's price, thus deterring all potential competition in that product market. This pricing advantage discourages new entrants from investing to develop a competing product.

Intellectual property protection similarly serves to deter competition. When a firm's protected intellectual property comes to dominate a market, competitors must invest time and resources in the development of competing technology to provide the goods or services that the dominant firm currently provides. But such large investments typically do not make good business sense due to the incumbent firm's unit cost advantage. The mere existence of a firm whose dominance is rooted in proprietary information thus discourages would-be market entrants and reinforces the incumbent's position.

Finally, network externalities can entrench a product and raise strong barriers to entry. Taking on an existing network is difficult because switching costs for individual consumers are particularly high as they stand to lose the benefits of participating in a popular network.

2. The Impact of Innovation. - Innovation is the predominant competitive force in the New Economy. ${ }^{74}$ Every year, technological advances render contemporary technologies less desirable, if not wholly obsolete. ${ }^{75}$ Although such technological change has always occurred, modern times are characterized by accelerated and more sig-

72 SHAPIRO \& VARIAN, supra note 39, at 22-23 (emphasis omitted).

73 David S. Evans \& Richard Schmalensee, $A$ Guide to the Antitrist Economics of Networks, ANTITRUST, Spring 1996, at 36.

74 LEER, supra note 35 , at 34-35 ("The nature of the industry is rapid change and the pressure is constantly on to come up with new, innovative products and winning gadgets.").

75 E.g., id. at 34 ("As soon as the product is bought, it seems, another and better version is launched."). 
nificant changes in technology. ${ }^{76}$ One implication of this rapid change is that dominance over a particular area is typically short-lived, not because a competitor will enter and provide that technology at a cheaper price, but rather because a competitor will develop a technology so superior as to overcome switching costs, and consumers will migrate toward the new offering as an emerging standard. ${ }^{77}$ As new technologies emerge, incumbents must discount their goods - a result that is good for consumers.

Furthermore, new technologies - or simply their threat - force dominant firms to participate in the drive to innovate. ${ }^{78}$ For example, though Microsoft dominated the pre-Windows operating system market with MS-DOS (Microsoft Disk Operating System), it nonetheless strove to innovate toward Windows for fear of losing the operating system market to a competitor offering superior technology. Such fears were not unfounded; it seems probable, though not guaranteed, that had personal computers (PCs) continued to use the MS-DOS system, Apple Computer's superior Macintosh environment would have become the preferred choice. Competitive pressures from other firms' innovations continue to force Microsoft to offer reasonable prices, to continue improving its products, and to participate in the effort to generate the Next Big Thing. ${ }^{79}$ Dominant firms realize that if they fail to innovate they will lose their position. ${ }^{80}$

3. Monopoly Power in an Information Technology Context. - The market dominance described above, coupled with the seemingly substantial barriers to entry that New Economy market forces tend to create, will lead to an inordinate number of findings of monopoly power for successful IT companies under traditional antitrust analysis. A full understanding of the operation of New Economy markets, and of the significance of innovation in IT markets, suggests that an alternative method of determining whether an IT firm possesses monopoly

\footnotetext{
76 Anne Leer demonstrates this point by comparing the 200-year lapse of time between the discovery of the eleventh and twelfth chemical elements with the twentieth century's discovery rate of one every three years. Id. at 32-33.

77 Brown \& McCollester, supra note 59, at 228 (noting that technological evolution and changing consumer demands "will cause market dominance to fade naturally").

78 Franklin Fisher, a veteran of the IBM antitrust battle, describes this phenomenon best: "[A] firm having forged ahead in the race may be in a better position than others to remain ahead, [but only if] it keeps running .... [T] [Te race is more like a marathon than a sprint." FRANKLIN M. Fisher, John J. MCGOWAN \& Joen E. GREenwood, Folded, SPINDLed, ANd Mutilated: ECONOMIC ANALYSIS AND U.S. V.IBM 35-36 (1983).

79 Microsoft chairman Bill Gates has stated:

The potential financial reward for building the "next Windows" is so great that there will never be a shortage of new technologies seeking to challenge it. ... That is one reason why we price Windows so low. If we increased prices, failed to innovate, or stopped incorporating the features consumers want, ... we would rapidly lose market share.

Bill Gates, Bill Gates Replies: Compete, Don't Delete, ECONOMIST, June I3, I998, at I9.

80 SHAPIRO \& VARIAN, supra note 39 , at I 73.
} 
power may be better able to ferret out firms that pose a real threat to consumer welfare. By broadening the traditional scope of the "relevant market" to account for the full competitive dynamic, replacing snapshot market share analysis with an evaluation of longitudinal market share, and by evaluating barriers to innovation rather than entry, courts will have a much more useful tool when they apply the first prong of the Grinnell test.

(a) The Relevant Market. - In an economy characterized by rapid innovation and competition among firms to provide network standards, market dominance is properly evaluated with respect to the broader market for a particular function that the product in question provides. This broader competitive dynamic consists of three spheres: competition within a network, competition between different networks, and competition to innovate beyond current technology.

The scope of the relevant market, then, should somehow reflect this more complete picture of the IT marketplace and the potential sources of substitutes for consumers. That would mean including in the determination of the relevant market under Grinnell's first prong the competing networks that could provide the same service or functionality and the potential alternative products available within the near future.

(b) Longitudinal Market Share Analysis. - Similarly, because of rapid innovation, an IT firm's market share at any given moment reveals little about its true market dominance and potential monopoly power. The rapidity of change in the knowledge economy signifies that the dominant firm of today may be outdone by new technology tomorrow. Therefore, at a minimum, a market share analysis must evaluate the market in question and the firm's position in it over an extended period of time to observe the progress of technological change..$^{81}$ The history of innovation in a particular area provides some insight into the future rate of innovation; any accurate assessment of a firm's dominance should take this rate into account.

(c) Barriers to Innovation. - Finally, in an environment of constant innovation, the barriers to entry described above can lose their significance in a Grinnell-style analysis. As mentioned earlier, courts will find that barriers to entry are not sufficiently significant to support a finding of monopoly power "when natural market forces will likely cure the problem." 82 In IT markets, innovation provides just such a natural market force. Innovation can emasculate entry barriers in a number of ways. Although high switching costs can raise substan-

81 See FISHER, MCGOWAN \& GREENWOOD, supra note 78, at 38 ("[I]n a market with rapid technological change ..., one must be sure to examine the market over a sufficiently long period of time to be able to observe the process of innovative competition at work.").

82 Rebel Oil Co. v. Atlantic Richfield Co., 5 I F.3d I42 I, I439 (gth Cir. I995). 
tial barriers to competition within or across networks, significant innovation beyond the incumbent standard can make the prospect of inducing consumers to switch much less daunting, as they migrate toward a better and usually cheaper product that meets their needs. Firms with superior technology offering a sufficiently improved product should have little difficulty supplanting an incumbent technology; the example of compact disc technology comes to mind. ${ }^{83}$

Given the ability of technological progress to reduce the significance of entry barriers in IT markets, a more relevant consideration is the extent to which there are barriers to innovation in the market. Such an approach would focus on factors in the marketplace that prevent or frustrate the development and marketing of alternative or improved technology. Evidence of such impediments could include, for example, the existence of limited relevant research facilities, all or most of which are under the control of the incumbent; monopolistic control over intellectual property or other resources crucial to the development of innovative alternatives; or the unavailability of distribution channels for newly developed products.

\section{Willful Acquisition or Maintenance of Monopoly Power in New Economy Markets}

Once a court identifies a monopoly, under Grinnell it must look for anticompetitive practices. The distinction between acceptable and anticompetitive behavior turns on whether the monopoly in question results from efforts to compete in the marketplace on the merits as opposed to efforts to stifle or exclude competition. ${ }^{84}$ How do the unique characteristics of the New Economy bear on this evaluation? The tendency of network effects, common standards, and lock-in effects to facilitate monopolization should allay concerns that IT market dominance has resulted from exclusionary conduct. An understanding of how firms must compete to survive in the context of these market forces is critical to an evaluation of whether certain practices serve legitimate business purposes or exclude competition in ways that warrant antitrust intervention.

I. Network Effects. - The topic of network effects has received much attention in academic discussions of competitiveness in the Information Age. ${ }^{85}$ The impact of network effects has also caused con-

83 Liebowitz and Margolis provide another example in the VCR standard battle. While Betamax technology enjoyed a first-mover advantage, VHS successfully challenged that standard because its longer. playing time offered the consumer superior technology. S.J. Liebowitz \& Stephen E. Margolis, Network Externality: An Uncommon Tragedy, 8 J. ECON. PERSP. 133, 147-48 (r994).

84 See supra p. 1627.

85 See, e.g., Symposium, The Changing Face of Efficiency, 7 Geo. MASON L. REV. 485 (1999). 
sternation among antitrust regulators, who in several speeches have highlighted increased antitrust concerns about network industries. ${ }^{86}$

Are these concerns warranted? Although it is clear that network effects foster single-firm market dominance, awareness of this tendency should make antitrust regulators less, not more, suspicious that anticompetitive practices are afoot. When they scrutinize a firm in a market characterized by network effects, regulators and courts should determine to what extent these effects cause market dominance. Other important considerations include whether the dominant firm is using proprietary information and whether the firm was a first-mover in its field. Affirmative answers to some or all of these questions should give antitrust authorities pause before they decide to intervene in the market; dominance that results from widespread consumer adoption of a technology is a natural and inevitable outcome in networked markets. Firms competing to provide a common standard should not be punished for their efforts. ${ }^{87}$ Such punishment would discourage them from providing the technology at all.

An appreciation of network effects should inform pricing evaluations as well. In any networked industry, competitors must engage in aggressive pricing strategies to gain market share. Penetration pricing is appropriate in this context as nothing more than a necessary approach to gaining market share or taking on an incumbent technology.88 Evidence of penetration pricing can include a firm's status as a newcomer to the market, a new and underdeveloped market, or a dwindling minority market share in need of remediation. In each of these circumstances, low- to no-price strategies are warranted - if not essential - given the challenges presented. Once a dominant player engages in such practices, however, it approaches the bounds of predatory pricing and regulators should become alert.

Antitrust regulators must keep in mind the significant benefits that consumers derive from participation in a network: consumers can be confident that their product will be compatible with those used by other consumers, that there will be a plentiful supply of complemen-

86 See, e.g., A. Douglas Melamed, Network Industries and Antitrust, Address Before the Federalist Society (Apr. Io, I 999), at http://www.usdoj.gov/atr/public/speeches/2428.htm; Rubinfeld, supra note 67; see also Steven C. Salop \& R. Craig Romaine, Preserving Monopoly: Economic Analysis, Legal Standards and Microsoft, 7 GEO. MASON L. REV. 617, 620-45 (1999) (discussing the arguments in favor of heightened antitrust scrutiny in network industries).

87 There is nothing illegal about such an outcome; Joel Klein acknowledged as much when he stated that "so far as the antitrust laws are concerned, businesses which have the skill and foresight to understand and take advantage of [network effects] are entitled to enjoy the fruits of their efforts." Klein, supra note $3 \mathrm{I}$.

88 See Kolasky, supra note 52, at 586 ("In such markets, a firm has more incentive to cut price because a reduction in price will increase the price-cutting firm's market share, thus making it even more attractive due to the increase in customers buying from it relative to its competitors."). 
tary goods, and that there will be a solid and dependable base of support for upgrades and service. Overly aggressive antitrust enforcement of network markets may interfere with these benefits and other network efficiencies, ultimately harming consumers. ${ }^{89}$

2. The Need for Common Standards. - When consumers demand a uniform standard for a technology, market dominance by the provider or providers of that standard is inevitable. Thus, the mere presence of a dominant firm in such a market should not raise antitrust concerns, particularly when the standard consists of intellectual property. ${ }^{90}$

Because the rewards for developing a product that becomes and remains the accepted standard are high, firms will compete vigorously for market positions. ${ }^{91}$ This competition will spur such practices as aggressively low pricing ${ }^{92}$ and exclusive-dealing arrangements. ${ }^{93}$ Once a standard prevails and dominates, however, antitrust authorities should remain on the sidelines: "If the market is a natural monopoly ... there would be no benefit in trying to force the market into a competitive structure with many overly small firms having excessively high production cost structures and low synchronization values for consumers." 94

Moreover, the need for standards is often so strong that reference to a product's superior quality or other merits - one of the undertones of a monopolization analysis - can become less significant to an evaluation of the appropriateness of a particular firm's market dominance. First-mover advantages and increasing switching costs that accompany growing market share can lead to the dominance and entrenchment of technologically inferior products. However, consumers should be able to choose an "inferior" technology if the benefits of participating in the common standard outweigh whatever shortcomings the product may possess. To the extent that a product is significantly inferior, history demonstrates that the market forces facilitating entrenchment will not protect it; ${ }^{95}$ competition in a world of standards is char-

89 See id. at 578 ("[T]he current focus on the 'dark side' of network effects may obscure the benefits network effects can deliver to consumers and may underestimate the potential for legal restraints to interfere with a network's ability to generate these efficiencies.").

90 Microsoft's Windows software is an example of a proprietary standard.

91 Ronald A. Cass \& Keith N. Hylton, Preserving Competition: Economic Analysis, Legal Standards, and Microsoft, 8 GEO. MASON L. REV. I, 36-38 (I g99) (noting that because the potential payoff for success is high, firms will be appropriately encouraged to vie for these markets).

92 Kolasky, supra note 52, at 605-06 ("Penetration pricing is likely to be natural, economically rational, efficiency-enhancing behavior in a market with positive network effects."

93 See Balto, supra note 53, at 526 ("Networks are often characterized by exclusivity arrangements.").

94 Liebowitz \& Margolis, supra note 58, at 301.

95 Consider again the example of the displacement of Betamax VCR technology. See Liebowitz \& Margolis, supra note 83 , at 2-4 (noting, based upon "rigorous examination of the historical rec- 
acterized by the continual displacement of incumbent technologies over time. ${ }^{96}$

3. Lock-In Effects. - Consumer lock-in primarily impacts pricing and barriers to entry. Once a firm has developed a committed customer base, it is difficult for a challenger to dislodge those customers. Courts and regulators must carefully distinguish difficulties that competitors face as a result of these forces from difficulties arising from anticompetitive conduct. It is natural and expected for a dominant firm with a committed customer base to engage in practices that will maintain and expand that base. ${ }^{97}$ Facilitating lock-in - through loyalty programs, low-cost upgrade deals, or promotional pricing, for example - is not anticompetitive behavior in this context. 98

Furthermore, given a locked-in base of consumers, value-based pricing, and switching costs, firms will price their goods at a level that takes into account the switching costs that consumers face. ${ }^{99}$ Once price exceeds switching costs, consumers will abandon the incumbent product and opt for its cheaper competitor. However, if switching costs are extremely high, consumer demand for the dominant firm's product will be quite inelastic, theoretically allowing a firm to charge a substantial amount for a good or service.

Such a situation, at first glance, may seem to merit antitrust intervention. Before such intervention, however, authorities must review the entire history of the incumbent firm's pricing in the market at issue. If the firm has employed vigorous price competition to achieve market dominance, deeply discounting its products to invest in market share, high prices are expected during the subsequent lock-in phase, as the firm must recoup its investment. 100 Consequently, seeming monopoly prices will not seem so high or unreasonable after factoring in the cost of the firm's initial investment. Regulators should permit the price of a product during a lock-in period to exceed the sum of the marginal cost of production, consumer switching costs, and the cost of original investment in market share enhancement.

There is a further antitrust implication here. Lock-in effects are enhanced by the dominant firms' competitive advantage derived from

ord," that "[o]bservable instances in which a dramatically inferior standard prevails are likely to be short-lived, imposed by authority, or fictional").

96 See id. at $29 \mathrm{r}$.

97 Paul Klemperer describes such practices as "investing in market share by charging a low price that attracts new customers who will be valuable repeat-purchasers in the future." Klemperer, supra note 6I, at 515 .

98 See SHAPIRO \& VARLAN, supra note 39, at II6-30.

99 See id. at 114 .

100 See Klemperer, supra note 61, at 521-22 (describing higher pricing by firms during the lockin phase and providing examples); Kolasky, supra note 52, at 605 (discussing firms' need to recoup their investments). 
better access to consumer demographic information. ${ }^{101}$ Therefore, additional pressures favoring market dominance exist independently of any anticompetitive behavior of firms. User registration programs, often a prerequisite for the receipt of customer service benefits, provide firms with valuable information about their consumer base. ${ }^{102}$ The possession of such information allows customization of content and a focused marketing approach. Firms able to avail themselves of such information and thus to garner the attention of consumers will be more successful at connecting people with their products. Dominant incumbent firms with established customer bases or the wherewithal to purchase customer information from others will be better able to master this aspect of the information economy, resulting in faster success.

4. Value-based Pricing. - An appreciation of value-based pricing is critical to a proper monopolization analysis in the New Economy. Under a regime of value-based pricing, firms offering products to customers who value those products differently will account for that difference when pricing them. For example, users of the same software may have different needs for customer support, product capabilities, or speed. Software developers can offer a stripped-down version of products for a lower price to ordinary consumers while charging professional users a deluxe rate for a product with expanded functionality. ${ }^{103}$ Therefore, when evaluating the price of a product, regulators must be sensitive to any versioning activity and the extent to which price is rooted in the value various market segments place on the goods or services.

5. Experience Goods. - Any antitrust analysis of pricing practices must take into account the experience-good aspect of information products. The experience-good problem spawns promotional pricing and product giveaways as a marketing strategy. If the good in question is offered below development cost, but it has yet to establish itself in the market, then promotional pricing, or even giving away the product, may be wholly rational business conduct. Without an understanding of this phenomenon, a necessary marketing approach for new and unestablished products can appear to be predatory conduct, especially when dominant players in the market engage in it.

\section{The Microsoft Case}

Turning briefly to Judge Jackson's evaluation of Microsoft's status as a monopolist, an application of the standards suggested in this Note would find Microsoft not liable under Section 2 of the Sherman Act.

101 SHAPIRO \& VARIAN, supra note 39, at 7.

102 Id. (describing the Hotmail Web-based Internet e-mail user registration process).

103 See id. at 55-63. 
I. Monopoly Power. - In its finding of monopoly power, the court limited the relevant market to "all Intel-compatible PC operating systems worldwide."104 This narrow conception of the relevant market led to the conclusion that Microsoft enjoyed a ninety-five percent market share. Taking into account the broader competitive dynamic would have led the court to consider competing networks such as the Macintosh operating system ${ }^{105}$ and other currently available or nascent products such as network computers or Internet appliances ${ }^{106}$ and handheld computing platforms such as the Palm OS. ${ }^{107}$ This larger swath of products encompasses the full array of alternatives that consumers face when they seek personal computing services. Because fully equipped PCs offer more power and capability than many consumers need, pared-down offerings outside of the Windows environment are becoming available for substantially lower prices. The proper question for Judge Jackson was whether Microsoft dominates this larger market.

Further inquiry would touch upon where Microsoft stands in the battle to provide consumers with the Next Big Thing. Computing appears to be moving from the one-size-fits-all approach of traditional PCs toward market segmentation based on particular functionalities that consumers desire, such as communications, web-surfing, entertainment, design, personal information organizing, and word processing. As this shift occurs, the market share of fully-equipped PCs erodes, thus eroding the dominance of Microsoft's operating system. Microsoft is not dominant among these emerging technologies; rather, a wide array of niche players has captured these valuable markets. ${ }^{108}$

With the relevant market rightly construed, Judge Jackson might not have found Microsoft so dominant. Indeed, considering the likely effects of a significant price increase reveals that Microsoft lacks monopoly power. Recall that the key to monopoly power is "the power to control prices or exclude competition." 109 If Microsoft charged the monopoly price for its operating system — an estimated \$I950, well

104 United States v. Microsoft Corp., 87 F. Supp. 2d 30, 36 (D.D.C. 2000).

105 The court did acknowledge that inclusion of the Macintosh OS in the relevant market would reduce Microsoft's market share to "well above" eighty percent. Id.

106 Scott Nesbitt, Introducing Internet Appliances, at http://netappliances.about.com/gadgets/ netappliances/library/weekly/aao7 2200 a.htm (last visited Feb. I9, 200 I).

107 Orr Shakked, Da-shan Shiu, Mark Sole \& Barbara Stone, The Hand-held Computers War, at http://www-inst.eecs.berkeley.edu/ eecsbar/s98/reports/eecsbaIf/project2.html (last visited Feb. I9, 200I).

108 See, e.g., James Lardner, PC Rebels Are Gaining: How Jeff Hawkins's PalmPilot Changed Computing (Mar. 22, I 999), at http://www.usnews.com/usnews/issue/990322/2 2 comm.htm.

109 United States v. E.I. du Pont de Nemours \& Co., 35 I U.S. 377, 39 I (I956). 
above the the $\$ 50$ currently charged ${ }^{110}$ - how would consumers respond? Consumers intent upon having a fully functional PC would keep the older version of Windows already on their computer; new computer purchasers would either purchase OS-free systems and purchase or pirate an older version of Windows or, more likely, migrate to non-Intel compatible computers such as the Apple Macintosh. Consumers who did not need all that a PC offers would purchase alternative technology, such as an Internet appliance. ${ }^{111}$ Competitors would swiftly introduce or increase sales of alternative or superior products to fill the vacuum.

Longitudinal market share analysis further undermines the Microsoft court's conclusions. Although Microsoft has been dominant in the Intel-compatible PC operating systems market for some time, it attained that dominance by successively improving products rather than marketing an unchanging product unresponsive to consumer demands. Since the time of MS-DOS, Microsoft has released multiple versions of Windows, each offering advances beyond its predecessor. ${ }^{112}$

More important, however, after the current paradigm shift away from PCs runs its course, the fate of Microsoft's dominance is uncertain. To condemn Microsoft's dominance in a field that new technologies may soon supplant is almost a purely academic exercise. Judge Jackson should have recognized that Microsoft is a player in a very dynamic environment and that observing Microsoft over the course of the next few years would be advisable before any judicial intervention.

Although. Judge Jackson correctly assessed the barriers to entry that prevent the development of viable alternative operating systems for Intel-compatible PCs, he did not consider whether there were significant barriers to innovation in the broader field of personal computing services. Indeed, the court acknowledged an array of budding alternatives such as hand-held computers, wireless web-browsing telephones, video game systems, and television set-top boxes; however, Judge Jackson did not consider these to be worthy adversaries for $\mathrm{Mi}$ crosoft. ${ }^{113}$ Whether they will ultimately supplant Microsoft or not, the fact remains that these products evidence a vibrant innovative envi-

110 See Bernard J. Reddy, David S. Evans \& Albert L. Nichols, Why Does Microsoft Charge So Little for Windowes?, at Section II.C. (1999), at http:/www.neramicrosoft.com/NeraDocuments/ Analyses/why_does_micro.html (last visited Nov. I 7,2000 ).

111 Internet appliances are synonymous with "thin clients," defined as "[a] server-centric computing model in which the application software, data, and CPU power resides [sic] on a network server rather than on the client computer(s)." Thin Client (Computing), in AMERICAN NATIONAL STANDARDS INSTITUTE, TELECOM GLOSSARY 2000, at http:/www.its.bldrdoc.gov/projects/ tI glossary2000/_thin_client.html (last visited Nov. I 7, 2000).

112 Pcbiography.com, Windows, at http://members.fortunecity.com/pcmuseum/windows.htm (last visited Nov. I7, 2000).

113 United States v. Microsoft Corp., 84 F. Supp. 2d 9, 15-I6 (D.D.C. 1999). 
ronment that promises to provide consumers with many substantial and attractive alternatives to the traditional PC. That no barriers exist to this innovation is directly relevant to whether Microsoft enjoys monopoly power; clearly, innovative alternatives would appear and gain market share were Microsoft to attempt monopolistic pricing behavior.

2. Anticompetitive Maintenance of Monopoly Power. - Microsoft has maintained its dominance in the market for Intel-compatible PC operating systems largely because the combination of New Economy market forces - network externalities, negligible marginal costs, and intellectual property protection - has entrenched Windows as the preferred standard among consumers. Neglecting this truth, the court instead focused on Microsoft's conduct vis-à-vis the Net-centric threats coming from Netscape and Sun Microsystems' Java technology.

Judge Jackson concluded that Microsoft's campaign to introduce a Web browser was designed to reduce Netscape Navigator's market share, thereby undermining Navigator's ability to become a platform for new Net-centered applications. ${ }^{114}$ Microsoft's Internet Explorer campaign can be seen as a textbook example of the development and successful marketing of an alternative standard in an IT market. Giving away Internet Explorer ${ }^{115}$ was a wise strategy in light of its negligible marginal cost and the need to facilitate consumer experience with it. Over time, Internet Explorer has become quite competitive with Netscape's browser, driving prices down while improving quality through newer versions. ${ }^{116}$

\section{CONCLUSION}

In the New Economy, as a result of network externalities, the cost structure of information goods, the need for standards, and consumer lock-in effects, there will inevitably be an increasing number of markets with only a few dominant players. Courts will find it increasingly simple to find that a firm has market dominance. But one should not automatically equate market dominance with monopoly power; the threat and reality of technological innovation often constrains the be-

114 United States v. Microsoft Corp., 87 F. Supp. 2d 30, 39 (D.D.C. 2000).

115 Microsoft, 84 F. Supp. $2 \mathrm{~d}$ at 44-45 (noting Microsoft's pricing of its browser at \$o).

116 David Evans \& Richard Schmalensee, The Economics of the Microsoft Antitrust Case: A Post-Trial Primer (Feb. II, 2000), at http://neramicrosoft.com/neradocuments/analyses/ aei_paper.htm. With respect to Microsoft's actions toward Java, the success of Java as a programming language and its near universal compatibility with all major operating systems, including Microsoft's Windows, demonstrate that any plot on the part of Microsoft to eliminate the Java threat - if there ever were one - was a supreme failure and had little to do with maintaining Microsoft's dominance in the Intel-compatible PC operating systems market. See id. (noting that "Java ... is doing just fine: all major operating systems now enable the use of programs written in 'cross-platform' Java"). 
havior of dominant firms. When such is the case, courts should hesitate to conclude that a firm has monopoly power under Grinnell.

In future applications of Grinnell's second prong, courts should recognize that in information markets the attainment of market dominance is often the natural outgrowth of vigorous competition, not anticompetitive behavior. Indeed, because the likelihood of market dominance in these markets is so high, competition for dominance will be robust: the prize of profitable market dominance is what provides firms with the incentives to invest and innovate. ${ }^{117}$ Thus, when confronted with a dominant New Economy firm, antitrust regulators and courts must consider the extent to which the relevant market naturally tends toward monopolization.

When courts examine firms' maintenance of their dominance, they should evaluate specific firms' conduct and business practices, bearing in mind the strategies necessary for survival and success in New Economy markets. Pricing structures are increasingly intricate and complex in the New Economy. With negligible marginal costs, firms must base their pricing decisions on consumers' valuations, a calculus that includes any perceived switching costs, the original cost of research and development, and the amount potentially invested in acquiring and maintaining market share through penetration pricing, giveaways, or other promotional loyalty programs. In addition, those firms seeking to gain a toehold in a valuable network market or standards battle will no doubt engage in penetration pricing. Old-style price evaluation methods will not suffice in this environment.

The New Economy presents firms with vibrant and ever-present competitive pressures. "Innovate or die" is the new mantra, as consumers continually demand better products at lower prices. Antitrust regulators must recognize that in an era of rapid technological change, market dominance comes and goes more rapidly, as innovation and progress continue to occur. This new paradigm does not imply that antitrust authorities should abdicate their responsibility to enforce the antitrust laws; rather, they ought to enforce the laws with an eye toward the realities of the marketplace in the new millennium.

117 See R.H. COASE, THE FIRM, THE MARKET, AND THE LAW I62 (I988). 